\title{
ORGANIC SOLVENTS AS CHEMICAL RISK FACTORS OF THE WORK ENVIRONMENT IN DIFFERENT BRANCHES OF INDUSTRY AND POSSIBLE IMPACT OF SOLVENTS ON WORKERS' HEALTH
}

\author{
Mārīte Ārija Baḳe, Maija Eglīte, Žanna Martinsone, Inita Buiḳe, Anita Piḳe, \\ and Pāvels Sudmalis
}

Institute of Occupational Safety and Environmental Health, Rīga Stradiṇš University, Dzirciema iela 16, Rīga, LV-1007, LATVIA

E-mail: marite.bake@rsu.Iv

Communicated by Māra Jure

\begin{abstract}
The aim of our study was to investigate organic solvents as chemical risk factors of the work environment in different branches of the industry in Latvia during 1998-2006 and to evaluate the possible impact of solvents to worker health according to the exposure index. The work conditions were studied in 116 enterprises of different branches of industries in Latvia. The analysis of 1790 measurements showed that organic solvents in the work environment have different degrees of exposure probability risk on worker health. The exposure levels in workplaces differ. More than half of surveyed workplaces (56.7\%) had a low organic solvent exposure probability level, in $25.2 \%$ workplaces it was medium, and in $18.1 \%$ workplaces high. The most widely used organic solvents were aromatic hydrocarbons, which was recorded in $35 \%$ of the measurements made during assessment of aromatic hydrocarbon group organic solvent exposure in the work environment. In most workplaces several solvents were present simultaneously. Since solvents have a one-way effect on the human body, the actual exposure risk level is higher than shown when evaluating the exposure index of a single solvent only.
\end{abstract}

Key words: risk factors of work environment, organic solvents, exposure indexes, chemicals of different classes.

\section{INTRODUCTION}

Organic solvents are a structurally, physically and chemically heterogeneous group of chemical compounds; the compounds they comprise have some common properties (high oil solubility, liquid state of aggregation, relatively low price), which is why they are widely used in different production processes (Xiao and Levin, 2000).

Organic solvents are a potential work environment risk factor for workers who are employed in sectors of economic activity such as production and use of lacquers and paints, chemical industry, engineering industry, wood processing, chemical laboratories, printing-houses, specific fields of medicine (diagnostic laboratories, disinfection activities), construction sector, dry cleaners, and car and motorcycle servicing. Handling of loose solvents (application of paints, dissolved in a solvent, by means of a pulveriser or brush on the surface) and simple defatting operations (for instance, defatting of metal surfaces before galvanization in defatting baths) are carried out both in small companies and in large and well-organised enterprises. All solvents used in the work process can be emitted in the work environment air in the form of vapour. Thus, a worker who is doing this work, as well as any other person present in the work room, can inhale chemical substances. Poisoning via the respiratory tract is the most dangerous, because gases and vapours of chemical substances are able to absorb through the respiratory mucous membrane along its entire length, travelling directly into blood and bypassing liver, which acts as a mechanical and biochemical barrier. When dealing with chemical substances and chemical products, for example, manually washing and defatting components, cleaning surfaces and spreading a coating, substances can be absorbed through skin. All of the mentioned oil soluble substances easily absorb through intact skin. Some substances can soften the upper layer of skin (solution of washing soda, solutions of surface-active substances), thus reinforcing the ability of other substances to absorb through the skin and penetrate into the blood. Since skin participates in the breathing process, gases can also absorb through the skin (Boman, 2000; Eglìte, 2000; Baķe, 2002).

Organic solvents can be characterised also by their physical risk determined by the physical and chemical properties and states of substances, of which the most important are com- 
bustibility, explosiveness, oxidability, reactivity, and material corrodibility. These properties cause risk of acute accidents in workplaces and the necessity to carry out particular safety activities (Anonymous, 2004).

Particular attention and occupational health and safety activities should be focused on organic solvents that can cause or promote development of malignant tumours, the socalled occupational carcinogens, for example, benzene and petroleum processing products containing benzene, styrene, chloroform and/or dichlorethane (Eglite, 2000; Anonymous, 2003).

There have been no investigations on survey on pollution by different solvents in the industrial working environment different solvents in Latvia. Only some data are available on chemical risk factors in the dry cleaning processes, as well as in health care organisations and hairdressers salons (Linnika et al., 2001; Bake et al., 2002 and 2003).

The aim of this study was to investigate organic solvents as chemical risk factors of the work environment in different fields of industry in Latvia during 1998-2006 and to evaluate the possible impact of solvents to worker health according to exposure index.

\section{MATERIALS AND METHODS}

The study material includes all organic solvent measurements in the air of workplaces made from 1995 till 2006 by the Hygiene and Occupational Diseases Laboratory of the Occupational and Environmental Health Institute at the Rīga Stradiňš University. Altogether, organic solvent measurements were made in 1790 workplaces in the breathing zone of worker by using individual sample taking devices by adsorption of organic substances on sorbents according to standard method (the occupational exposure evaluation of each substance represents the results of three consecutive measurements, for the sake of convenience further in the text we use the term - measurements). The occupational exposure measurements of organic solvents were carried out in 116 companies and their branches, encompassing $22 \mathrm{sec}-$ tors of national economy. Company codes are given according to statistical classification of economic activities NACE (Nomenclature statistique des activités économiques dans la Communauté Européenne).

To obtain more representative information, measurements of occupational exposures of 30 organic solvents included in the database were analysed. The solvents were classified by similar structure in the eight groups: aromatic hydrocarbons, total hydrocarbons, esters, ketones, petroleum distillates, celosolves, halogenhydrocarbons, and alcohols. Of 1790 inspected workplaces, no organic solvents were determined in air only in seven cases (concentration lower than the limit determined by the method).

The concentration of solvents in the working environment was determined using ISO and LVS (Latvian state standard) methods and modern equipment (gas chromatograph Varian
3800 with FID and ECD detectors) at the Hygiene and Occupational Diseases Laboratory (accredited by LATAK T-049-96).

Evaluation of measurements according to exposure index. The leading regulatory document regulating concentration of chemical substances and products in the work environment is the Regulation of the Cabinet of Ministers No. $325 / 2007$, "Labour protection requirements when workers come in contact with chemical substances in the work environment". This document gives the requirements that workers must observe when they come into contact with chemical substances in workplaces, where risk can arise from the exposure to substances present in the work environment or connected with the work process. For the assessment of probability of health risk caused by the occupational exposure to chemical factor in the work environment, the exposure index (EI) is used, which shows the degree of occupational exposure of chemical substance and at the same time provides information on the probability of the effect of the chemical substance on workers' health. The exposure index is based on the actual concentration of the chemical substance in the work environment in relation to the occupational exposure limit (OEL) value set in legislation for each substance. By applying the exposure index it is possible to carry out assessment of joint exposure risk of different chemical substances irrespective of their individual numerical values.

During the last 15 years, the occupational exposure limit value for some chemical substances has changed considerably, while for others it has remained unchanged (see established OEL and regulatory documents in Table 1).

The exposure indexes of organic solvents with low, medium and high exposure degrees are divided into three groups/ classes. The first group, with an exposure index less than or equal to 0.1 , shows a low exposure probability of the chemical substance. The second group $(0.1<\mathrm{EI} \leq 0.75)$ shows a medium exposure probability. The third group $(\mathrm{EI}>0.75)$ reflects a high exposure probability. Measurements of the occupational exposure of chemical factors admit a $25 \%$ error, therefore, the third class EI indicates separate an exceeded occupational exposure limit value.

The statistical processing of the study results was implemented by employing SPSS 14.0 software (company SPSS Ltd., USA). In the statistical data analyses, adequate methods were used (Altman, 2003; Teibe, 2007).

\section{RESULTS}

Results broken down by sector of national economy. Occupational exposure measurements of organic solvents were carried out in 116 companies and their branches encompassing 22 sectors of the national economy according to NACE classification codes (Table 2). The number of organic solvent measurements made has been growing yearly. Most of the measurements $(35.7 \%)$ were made in the 12 different 
OCCUPATIONAL EXPOSURE LIMIT (OEL) CONCENTRATION FOR STUDIED ORGANIC SOLVENTS ANALYSED WITHIN THE RESEARCH (INDIVIDUAL CHEMICAL SUBSTANCES) IN 1994-2006

\begin{tabular}{|c|c|c|c|}
\hline Chemical substance & $\begin{array}{l}\text { Hygiene regu- } \\
\text { lation, } \mathrm{mg} / \mathrm{m}^{3}\end{array}$ & $\begin{array}{c}\text { LVS 89:1998, } \\
\mathrm{mg} / \mathrm{m}^{3}\end{array}$ & $\begin{array}{c}\text { LVS 89:2004, } \\
\mathrm{mg} / \mathrm{m}^{3}\end{array}$ \\
\hline Acetone & 200 & 200 & 1210 \\
\hline Benzene & $5 / 15^{*}$ & $5 / 15^{*}$ & 3.25 \\
\hline Petrol / petroleum & 100 & 100 & 100 \\
\hline Butyl alcohol & 10 & 10 & 10 \\
\hline Cyclohexanone & 10 & 10 & 40.8 \\
\hline Ethanol & 1000 & 1000 & 1000 \\
\hline Ethylbenzene & 50 & 50 & 442 \\
\hline Ethylcelosolve & 10 & 10 & 10 \\
\hline Acetic acid butyl ester & 200 & 200 & 200 \\
\hline Acetic acid ethyl ester & 200 & 200 & 200 \\
\hline Chloroform & - & $10 / 25$ & 10 \\
\hline Isopropyl alcohol & 10 & $350 / 600^{*}$ & $350 / 600^{*}$ \\
\hline Isobutyl acetate & - & - & 200 \\
\hline Xylenes & 50 & 50 & 221 \\
\hline Ligroin / white spirits & 300 & 300 & $200 / 300 *$ \\
\hline Methanol & 5 & 260 & 260 \\
\hline Methyl acrylate & 5 & $20 / 35^{*}$ & $20 / 35^{*}$ \\
\hline Methyl metacrylate & 10 & 10 & 10 \\
\hline Methyl propylcelosolve & - & - & 375 \\
\hline Mineral oils & 5 & 5 & 5 \\
\hline Hydrocarbons (total by C) & - & 300 & $100 / 300^{*}$ \\
\hline Kerosene & 300 & 300 & $100 / 300^{*}$ \\
\hline Propyl alcohol & 10 & 10 & 10 \\
\hline Styrene & $10 / 30 *$ & $10 / 30 *$ & $10 / 30 *$ \\
\hline $\begin{array}{l}\text { Tetrachloroethylene / } \\
\text { perchloroethylene }\end{array}$ & 10 & 10 & 10 \\
\hline Tetrachlorocarbon & 20 & 20 & 20 \\
\hline Toluene & $50 / 150^{*}$ & $50 / 150^{*}$ & $50 / 150^{*}$ \\
\hline Trichloroethylene & - & 10 & 10 \\
\hline Vinyl acetate & 10 & 10 & 10 \\
\hline
\end{tabular}

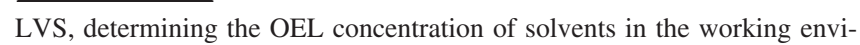
ronment.

* numerator presents 8-hour OEL, and denominator - a short-term OEL (15 min) value.

sectors of the production industry (from DA till DN), followed by 354 measurements (19.8\%) made in companies operating in the fields of power, gas and water supply (E code in NACE) - 188 measurements (10.5\%) in wholesale and retail trade sectors; repair of motorcars, motorcycles, individual articles, household equipment and devices (code G) and 198 measurements (10.6\%) in transport, rescue and communication sector (code I).

Organic solvent groups in different sectors of economic activity. Most measurements $(643,35 \%)$ were made to determine the exposure of organic solvents of the aromatic hydrocarbon group in the work environment (Fig. 1). Of these, toluene, xylenes and benzene were detected in 238, 215 and 201 measurements, respectively). 19\% (336 in total) of measurements were to determine aliphatic hydrocarbons as
OCCUPATIONAL EXPOSURE MEASUREMENTS OF ORGANIC SOLVENTS MADE IN SECTORS OF THE NATIONAL ECONOMY (COMPANY CODES ACCORDING TO NACE CLASSIFICATION) AND NUMBER OF ASSESSED COMPANIES

\begin{tabular}{|c|c|c|c|c|}
\hline \multirow[t]{2}{*}{$\begin{array}{l}\text { NACE } \\
\text { code }\end{array}$} & \multirow[t]{2}{*}{ Type of economic activity } & \multirow[t]{2}{*}{$\begin{array}{l}\text { Number of } \\
\text { companies }\end{array}$} & \multicolumn{2}{|c|}{$\begin{array}{c}\text { Number of } \\
\text { measurements }\end{array}$} \\
\hline & & & $\mathrm{N}$ & $\%$ \\
\hline A & $\begin{array}{l}\text { Forestry, timber preparation } \\
\text { and related services }\end{array}$ & 5 & 15 & 0.8 \\
\hline DA & $\begin{array}{l}\text { Foodstuff, beverage and to- } \\
\text { bacco production }\end{array}$ & 1 & 4 & 0.2 \\
\hline DB & Textiles production & 1 & 1 & 0.1 \\
\hline DC & $\begin{array}{l}\text { Leather processing and pro- } \\
\text { duction of leather articles }\end{array}$ & 1 & 23 & 1.3 \\
\hline DD & $\begin{array}{l}\text { Production of timber and } \\
\text { wood articles }\end{array}$ & 3 & 51 & 2.8 \\
\hline $\mathrm{DE}$ & $\begin{array}{l}\text { Production of cellulose, pa- } \\
\text { per and paper articles; pub- } \\
\text { lishing and printing indus- } \\
\text { try }\end{array}$ & 8 & 120 & 6.7 \\
\hline DG & $\begin{array}{l}\text { Production of chemical } \\
\text { substances and chemical } \\
\text { fibres }\end{array}$ & 5 & 124 & 6.9 \\
\hline DH & $\begin{array}{l}\text { Production of rubber and } \\
\text { plastic material articles }\end{array}$ & 4 & 35 & 2.0 \\
\hline DI & $\begin{array}{l}\text { Production of non-metallic } \\
\text { mineral articles }\end{array}$ & 1 & 12 & 0.6 \\
\hline DJ & $\begin{array}{l}\text { Production of metal and } \\
\text { metal articles }\end{array}$ & 13 & 143 & 8.0 \\
\hline DK & $\begin{array}{l}\text { Manufacturing of equip- } \\
\text { ment, mechanisms and ma- } \\
\text { chine tools }\end{array}$ & 2 & 7 & 0.4 \\
\hline DL & $\begin{array}{l}\text { Manufacturing of electric } \\
\text { and optical equipment }\end{array}$ & 3 & 21 & 1.2 \\
\hline DN & $\begin{array}{l}\text { Industrial production not } \\
\text { listed elsewhere; furniture } \\
\text { production }\end{array}$ & 4 & 98 & 5.5 \\
\hline $\mathrm{E}$ & $\begin{array}{l}\text { Power, gas and water sup- } \\
\text { ply }\end{array}$ & 5 & 354 & 19.8 \\
\hline $\mathrm{F}$ & Construction & 12 & 113 & 6.3 \\
\hline G & $\begin{array}{l}\text { Wholesale and retail trade; } \\
\text { repair of motorcars, motor- } \\
\text { cycles, household equip- } \\
\text { ment and devices }\end{array}$ & 11 & 188 & 10.5 \\
\hline I & $\begin{array}{l}\text { Transport, rescue and com- } \\
\text { munication }\end{array}$ & 12 & 189 & 10.6 \\
\hline $\mathrm{J}$ & Financial mediation & 1 & 4 & 0.2 \\
\hline $\mathrm{K}$ & $\begin{array}{l}\text { Real estate transactions, } \\
\text { lease, computer services, } \\
\text { science and other commer- } \\
\text { cial services }\end{array}$ & 3 & 18 & 1.0 \\
\hline $\mathrm{L}$ & $\begin{array}{l}\text { Public administration and } \\
\text { defence; mandatory social } \\
\text { insurance }\end{array}$ & 2 & 71 & 4.0 \\
\hline $\mathrm{N}$ & Health and social care & 10 & 116 & 6.5 \\
\hline $\mathrm{O}$ & $\begin{array}{l}\text { Public, social and individ- } \\
\text { ual services }\end{array}$ & 9 & 83 & 4.6 \\
\hline Total & & 116 & 1790 & 100 \\
\hline
\end{tabular}

NACE, Nomenclature statistique des activités économiques dans la Communauté Européenne). 


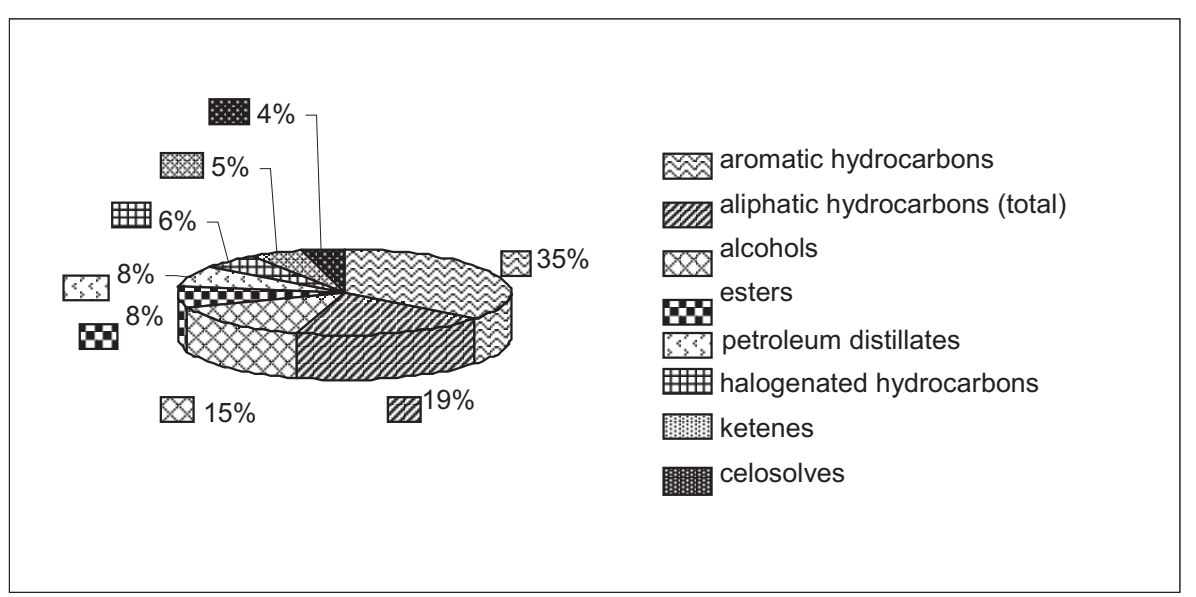

Fig. 1. Distribution of organic solvents by chemical compound groups (in \%). sum calculated according to amount of carbon $\mathrm{mg} / \mathrm{m}^{3}$. Widespread alcohols found in 263 measurements were isopropanol, butanol and ethanol (90, 71 and 66 measurements, respectively). In the 140 measurements of esters, butyl acetate, ethyl acetate and methyl akrylate predominated. The petroleum distillates were represented mostly by white spirit (lackbensin) and ligroin (a saturated hydrocarbon petroleum fraction), these had 140 measurements. $75 \%$ of measured halogenated hydrocarbons in the working environment consisted of perchloroethylene (tetrachloroethylene) in dry cleaning offices (75 of 103 measurements). The total number of measurements made for detection of ketenes and celosolve group organic solvents was 92 and 73 measurements, respectively).

The measurements show that petroleum hydrocarbons (particularly aromatic compounds) are used as solvents nearly in all manufacturing sectors, and the number of measurements for this group of compounds was the largest, but in some sectors only specific exposure measurements of one group of solvents were made, for example, summary hydrocarbons in textile production (DB); (J) - halogen hydrocarbons in financial and municipal services, including dry cleaning; and alcohols and ketenes and a little esters in production of metals and non-metallic mineral articles (DI). The largest number of measurements in health care companies was for alcohol group compounds, mainly isopropanol, which is used in disinfection.

Taking into account the small number of measurements made in separate sectors and general requirements of statistical processing, the percentage breakdown of measurements by organic solvent groups in different sectors of national economy is not analysed in detail. For further analyses, there were selected sectors where the number of made measurements was sufficient for statistical analyses; some sectors where companies had similar character of activities were joined in one group. Power, gas and water supply sector (code E); wholesale and retail trade sectors; repair of motorcars, motorcycles, individual articles (code G); and transport, rescue and communication sector (code I) were joined, since work was connected with servicing of mechanical equipment. The sector of timber and wood article production (code DD) and sector of industrial manufac- turing not listed elsewhere (code DN) were joined because work involved timber processing and furniture production work processes.

The analysis of results of measurements shows that operation of mechanical equipment in related sectors $(E+G+I)$, in furniture manufacturing sectors (DD+DN), cellulose, paper and paper articles; publishing and printing industry (code DE) and in the sector of metal and metal article production (DJ) the largest part of measurements were for aromatic hydrocarbons $(43 \%, 35 \%, 27 \%$ and $21 \%$, respectively), and in the health and social care sector (code N) $74 \%$ measurements were aimed at the determination of occupational exposure of alcohol group chemical compounds.

Evaluation of measurements according to exposure index. For assessment of probability of health risk caused by the occupational exposure to chemical factors in the work environment the exposure index (EI) is represented in Figure 2 with breakdown by the 22 sectors of economic activity.

In the sector of leather processing and production of leather articles (code DC) in $73.9 \%$ of assessed workplaces the exposure level of organic solvents exceeded $75.0 \%$ of the occupational exposure limit value (i.e. EI > 0.75); in the sector of public, social and individual services (code $\mathrm{O}$ ), which is mainly connected with dry-cleaning, high exposure was shown in $69.9 \%$ of assessed workplaces.

Several solvents were simultaneously present in the work environment air of most workplaces. Since the solvents have a one-way effect on the body, the actual risk degree is higher than shown when assessing the exposure index of only one solvent.

Taking into account the small number of measurements made in individual sectors and the general statistical processing requirements, in the same way as when assessing the percentage breakdown by the groups of organic solvents in different sectors of national economy, the percentage breakdown of exposure indexes of organic solvents by groups in different sectors of national economy is not analysed in detail. However, there was a large number of measurements with high exposure index in leather processing 


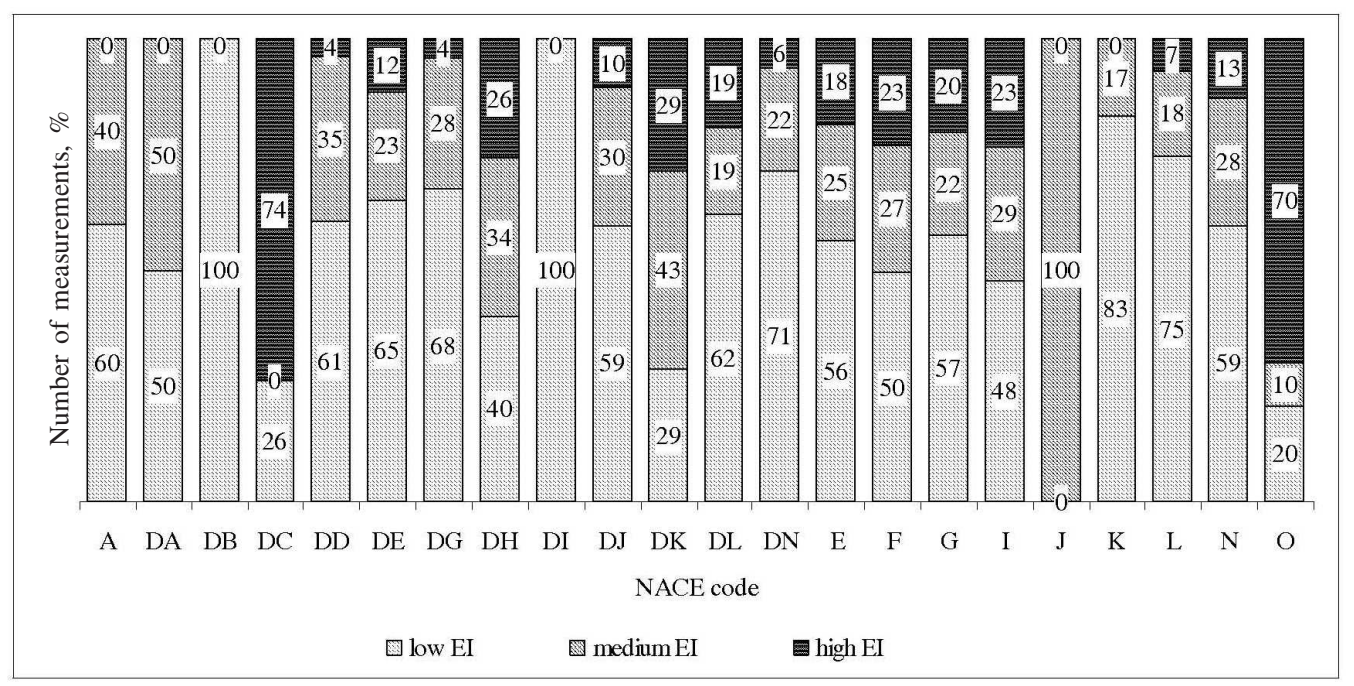

Fig. 2. Exposure indexes (EI, \%) of organic solvents by classes (low, medium and high) in sectors of economic activity in Latvia according to data of the Laboratory of Hygiene and Occupational Diseases.

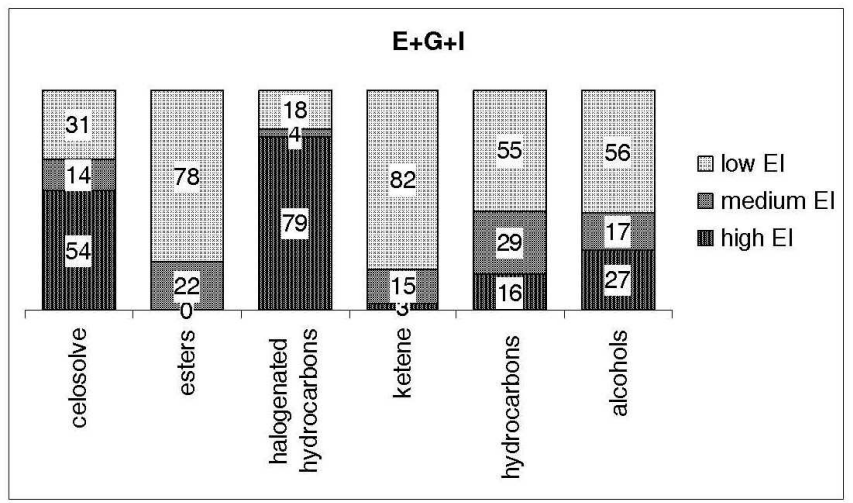

Fig. 3. Exposure index (EI, \%) depending on the solvent group exposure in sectors related to the operation of mechanical equipment (NACE codes E, G, I).

and leather articles production (DC - 73.9\%) and in the sector of public, social and individual services $(\mathrm{O}-69.9 \%)$.

The results of the exposure index in the sectors selected for analyses depending on the concrete solvent show that there is a high proportion of organic solvents of halogen hydrocarbon group and celosolve group in sectors related to the operation of mechanical equipment (Fig. 3).

Exposure indexes characterising the work environment, depending on the group of organic solvents, are given in the Table 3. A high exposure index of the group of aromatic hydrocarbons and summary hydrocarbons was found in 76 cases, and high exposure index of halogen hydrocarbon group organic solvents in 74 cases.

\section{DISCUSSION}

Occupational exposure of organic solvents is assessed by groups of organic solvents. Solvents on a petroleum base were analysed separately, breaking them down into aromatic hydrocarbons, petroleum distillates and total determined hydrocarbons. Since the effects on health caused by solvents of these groups are similar and they have similar chemical origin, for the sake of convenience they are combined in a hydrocarbon group.
Table 3

NUMBER OF MEASUREMENTS OF ASSESSED WORKPLACES FOR SOLVENTS BY EXPOSURE GROUPS (LOW, MEDIUM AND HIGH) IN LATVIA ACCORDING TO DATA OF THE LABORATORY OF HYGIENE AND OCCUPATIONAL DISEASES

\begin{tabular}{l|c|c|c}
\hline \multicolumn{1}{c}{ Solvent group } & \multicolumn{3}{c}{ Exposure index } \\
\cline { 2 - 4 } & low & medium & high \\
\hline Aromatic hydrocarbons & 435 & 132 & 76 \\
Celosolves & 36 & 9 & 28 \\
Esters & 89 & 37 & 14 \\
Halogenated hydrocarbons & 12 & 17 & 74 \\
Ketenes & 77 & 11 & 4 \\
Petroleum distillates & 58 & 62 & 20 \\
Alcohols & 162 & 68 & 33 \\
Total hydrocarbons & 146 & 114 & 76 \\
Total & 1015 & 450 & 325
\end{tabular}

In the studied sectors of the national economy, except health and social care sector, organic solvents of the hydrocarbon group were the most widely used, shown by the large number of occupational exposure measurements made.

In the sectors of economic activity where the work is connected with the operation of mechanical equipment and motor transport (NACE codes - E, G, I), hydrocarbon group solvents are very widely used $(76 \%$ of measurements made to determine the occupational exposure). Workers employed in these sectors are exposed to organic solvents when repairing equipment - pumps, motors, defatting and painting components, transporting and refilling fuel.

In furniture manufacturing (NACE codes DD and DN) organic solvents of hydrocarbon group and ester group are widely used - $45 \%$ and $33 \%$ of occupational exposure measurements, respectively. Solvents of both groups are ingredients of lacquers and paints, which are extensively used in this sector. In this sector solvents of alcohol group are also commonly used; the proportion of occupational exposure measurements was $19 \%$. 
In the assessed workplaces of the cellulose, paper and paper articles production, publishing and printing industry sector (NACE code DE) hydrocarbon group solvents are widely used (52\% measurements) along with alcohol group organic solvents (18\%). Hydrocarbon group solvents are ingredients of typographic paints; aromatic hydrocarbon group and alcohol group solvents are widely used for the cleaning of printing equipment.

In the metal and metal production sector (NACE code DJ) hydrocarbon group organic solvents are dominating (65\% assessments), as these solvents (particularly - petroleum fraction white spirit and kerosene) are widely used in different defatting and purification processes; hydrocarbons are constituents of many paints, lacquers and solvents.

In the field of application of organic solvents the health and social care sector (NACE code N) differs essentially from other sectors of national economy, as $74.0 \%$ measurements are made for determining occupational exposure of alcohol group solvents of which $12.9 \%$ showed a high exposure index. This is explained by wide use of alcohols (isopropyl alcohol and ethyl alcohol) in disinfectants (Parmeggiani, 1985).

In general in $81.8 \%$ of the assessed workplaces the probability of organic solvent exposure is low or medium (the EI there is low or medium). In $18.2 \%(15.6 \%-20.7 \%)$ of assessed workplaces there was a high probability that the occupational exposure of organic solvents might affect employee health. The high exposure index standard error (1.3) indicates large variability in this class (range 0.75 to a total of 223 indicating an exposure limit value exceeded by more than 200 times).

In sectors related to the servicing of motor cars and mechanical equipment the workers are exposed to higher hydrocarbon and celosolve risk, which is shown by the high proportion $(20.1 \%)$ of measurements with high exposure index. The hydrocarbon group solvents have a lasting effect on the human body and can cause irreversible health disorders. They have a toxic effect on the nervous system, causing functional and organic damage to the central and peripheral nervous system. Benzene and petrol have a carcinogenic effect and hydrocarbon group solvents can influence man's reproductive ability and also development of foetus. Vapour of both group solvents irritates eyes and skin (Lacey, 1999; Plenge-Bönig, 1999; Eglīte, 2000; Shi, 2001; Triebig, 2001; Dick, 2006). In the mechanical equipment sector employers must plan replacement of hydrocarbon group organic solvents; more attention should be paid to the optimisation of production processes to reduce the emission of organic solvents into the work environment, and protective equipment should be used to reduce exposure to risk of chemical factors.

The high proportion of workplaces with high exposure index in the sector of public, social and individual services (NACE code $\mathrm{O}$ ) is due to the situation in the field of dry cleaners, where the initial processing of clothes is made in closed systems using the halogen hydrocarbon group solvent perchloroethylene, afterwards clothes are sorted, stains are removed and ironing is done in open premises. In this sector $60 \%$ of all measurements were made to assess the halogen hydrocarbon occupational exposure; on average, in $70 \%$ of cases the probability of this halogen hydrocarbon exposure risk was classified as high. The concentration of specific halogen hydrocarbon class organic solvents in the air exceeded the occupational exposure limit value by several tens of times, causing very high risk. Since the carcinogenic character of perchloroethylen has been partly proved, the situation in the assessed occupational environment in dry cleaners' calls for prompt action from the employers, and should be aimed at the optimisation of the work process and reduction of the emission of harmful chemical factors (Eglìte, 2000; Linnika, 2001; Xiao, 2000; Shi, 2001).

The obtained results show a similar picture with the data referred to in the literature on high organic solvent occupational exposure probability in the workplaces of automotive industry, furniture production, printing and publishing industry and dry cleaners' services (Parmeggiani, 1985; Pesch, 2000; Lash, 2001; Triebig, 2001; Dick, 2006).

The measurements made on hydrocarbon group exposure indexes have the following distribution: low exposure index $56.7 \%$, medium exposure index $25.2 \%$, and high exposure $18.2 \%$ of inspected workplaces/production processes. Although low and medium exposure index was observed in $81,8 \%$ of workplaces, the risk probability assessment is not unequivocal, because studies show that a long-term low occupational exposure of hydrocarbon class solvents (EI 0,1) can cause functional disorders of the nervous system and reduce sensibility to vibration (Xiao, 2000).

Because of the limited amount of data, it is not possible to assess the distribution of occupational exposure of separate organic solvents by different workplaces. Although the database of the Hygiene and Occupational Diseases Laboratory of the Occupational and Environmental Health Institute contains a large number of measurements, it covers a long period of time from 1995 to 2006, and the data entry procedure charged over time regarding specification of the field of economic activity. The evaluation of the work environment chemical factor exposure (number of measurements) in many sectors is insufficient; sometimes only one chemical factor was measured in one workplace, and thus the results in this field are not representative. The database comprises measurements on the occupational exposure of 30 organic solvents; the number of measurements of an individual solvent and within the groups of solvents is insufficient, and therefore, it is not possible to make a comparative assessment of exposure limits of all organic solvents.

The effect of organic solvents on worker health. There are multiple effects of organic solvents on the human body, depending on the solvent's physical and chemical properties, chemical structure and activity, as well as on the metabolic features. The effect can be acute and chronic. Since solvents have a one-way effect on the human body, the ac- 
tual exposure risk is higher than that estimated by exposure index of a single solvent only.

Acute effect of organic solvents is observed in cases of accidents when occupational safety rules have been violated and the occupational exposure limit value is exceeded by tens of times, and also when solvents penetrate into the body through the gastrointestinal tract (Eglite, 2000; Dick, 2006). In cases of acute occupational poisoning, solvents can affect the body non-specifically, causing disorders of central nervous system - headache, giddiness, narcotic effect (nearly all volatile, oil soluble organic solvents), which can develop into unconsciousness, cramps and even death. Other non-specific effects are skin irritation, conjunctivitis, irritation of pharynx and respiratory tract mucosa, which arise due to defatting action of solvents. The specific effect depends on the solvent's chemical activity and the effect caused by its metabolic products. For example, poisoning with benzene and its homologues can cause disturbance of regulation of the central haematogenic system; in the case of poisoning with hydrocarbon halogen derivatives, liver and kidney damages and body sensibilization can occur (Eglīte, 2000; Triebig, 2001; Dick, 2006).

Chronic poisoning with organic solvents can occur in persons who for several years have worked in premises with high concentration of organic solvents in the air. In cases of chronic poisoning most often affected are both central and peripheral nervous systems, as well as other organs and organ systems (Boman, 2000; Eglīte, 2000; Triebig, 2001; Dick, 2006).

During the two last decades epidemiological research has described a relationship between lasting occupational exposure to organic solvents and non-specific symptoms, such as headache, fatigue, irritability, memory disturbances, reduced intellectual abilities, concentration difficulties, emotional instability, depression, sleep disorders, reduced alcohol tolerance, reduction of libido and potency and alters aging processes (Xiao, 2000; Nilson, 2002).

Because of the chronic irritating and defatting effect of organic solvents, dermatitis, conjunctivitis and chronic breathing tract inflammation can develop. The irritation features in aromatic organic solvents are more expressed than in aliphatic compounds. Halogen derivatives of organic solvents after direct contact with skin can cause erythema, ulcers, burns; halogen hydrocarbons have a marked specific hepatotoxic effect and they can cause liver damage. There is a high risk of non-specified systemic connective tissue damage to workers working with petroleum distillates. Organic solvents have also sensibilising properties (Eglīte, 2000; Boman, 2000; Lacey, 1999; Xiao, 2000).

Children of pregnant women who during the first trimester of pregnancy have worked with organic solvents (glycol ether/celosolve, toluene, halogen hydrocarbons) face an increased risk of congenital anomaly and a possible risk of spontaneous abortion. A significant relationship was observed between the mother's work with lacquers and paints and congenital heart anomalies (Xiao, 2000; Shi, 2002).
Petroleum processing products, for example petrol, which sometimes is used as solvent, can contain benzene, which the International Agency for Research of Cancer (IARC) has classified as a first group carcinogenic substance causing leukaemia and other diseases of haematogenic system to the exposed population. The group of substances, probably carcinogenic to men, detected in measurements in this research, includes epichlorohydrin, tetrachlorocarbon, chloroform, trichloroethylene, and ethylenchloride (Xiao, 2000). Tetrachloroethylene (perchlorethylene) in the occupational environment increases risk to develop non-Hodgkin's lymphoma, cancer of uterine neck, alimentary tube, bladder and kidneys (Pesch, 2000; Lash, 2001). It has been stated that organic solvents have a probable role in the development of exocrine pancreas (Alguacil, 2002).

The conclusions are:

1. In view of the available data, organic solvents should be regarded as an important work risk problem in Latvia; however, in Latvia there are no available detailed data either on the number of workers exposed to organic solvents in the work environment, or on the consequences caused by organic solvents.

2. The analyses of the controlled emissions in the last three years show that in production (particularly in the processing industry) large amounts of different solvents are used, both as technical mixtures (white spirits, kerosene) and as the so-called mixed solvents, comprising aromatic hydrocarbons (toluene, xylenes), esters, (ethylacetate, butylacetate), alcohols (butanol, ethanol, isopropanol), ether type compounds (ethylcelosolve) and ketenes (acetone). The largest consumption of solvents is in furniture and timber article production (lacquering and painting processes) and metal and metal article production (defatting and cleaning of metal surfaces and also painting).

3. In the sectors of economic activities where the work of the employed is associated with the operation of mechanical equipment and motor transport is a tendency to widely use hydrocarbon group organic solvents, as $76 \%$ of measurements of chemical substances were made in this sector. In the second place, in metal and metal article production sector, $65 \%$ of measurements were of hydrocarbon class solvents, and the third place was taken by cellulose and paper production, publishing and printing industry (52\% of evaluations).

4. The most widely used hydrocarbon group of organic solvents were aromatic hydrocarbons, as $35 \%$ of measurements of this group were made to determine the exposure of aromatic hydrocarbon group organic solvents (toluene, xylenes, benzene, styrene) in the work environment.

5. In the furniture production and timber processing hydrocarbon group and ether group organic solvents are widely used. For determination of these solvents, $45 \%$ and $33 \%$ measurements of occupational exposure were made.

6. Persons employed in health care are exposed mainly to alcohol group (isopropanol, ethanol) organic solvents 
shown by the high proportion (74\%) of measurements of these group compounds made in the work places.

7. In the dry cleaner companies and in the public, social and individual service sector, a high halogen hydrocarbon (perchloroethylene) exposure risk was found shown by a high proportion of high and very high exposure indexes $(70 \%)$ in the work environment.

8. Organic solvents in the work environment have different exposure risk to worker health detected by use of exposure indexes: the exposure levels in different workplaces differ - more than half of surveyed workplaces $(56.7 \%)$ had a low organic solvent exposure, in $25.2 \%$ workplaces it was medium, and in $18.1 \%$ workplaces - high.

9. In the work environment air, in most work places several solvents were present simultaneously. Since solvents have one-way effect on human body, the actual exposure risk is higher than indicated by the exposure index of a single solvent only.

\section{ACKNOWLEDGMENTS}

The research was conducted within the Project "Studies of the Ministry of Welfare" No. VPD1/ESF/NVA/04/NP/ 3.1.5.1./0003 of the National Programme "Labour Market Studies" and financed by European Structural Fund.

\section{REFERENCES}

Alguacil, J., Porta, M., Malats, N., Kauppinen, T., Kogevinas, M., Benavides, F.G., Partanen, T., Carrato, A. (2002). Occupational exposure to organic solvents and K-ras mutations in exocrine pancreatic cancer. Carcinogenesis, 23, 101-106.

Altman, D.G. (2003). Practical Statistics for Medical Research. London: Chapman and Hall, 606 pp.

Anonīms (2003). Ar kancerogēnu iedarbību saistīto darba vides risku novērtēšanas un novēršanas vadlīnijas [Guidelines for Detection and Prevention of Cancerogenic Risk Factors]. ES PHARE Latvijas - Spānijas divpusējās sadarbības projects. Rīga: Labklājības ministrija, 52 lpp.

Anonymous (2004). Darbs sprādzienbīstamā vidē [Work in Explosive Environments]. ES PHARE Latvijas - Spānijas divpusējās sadarbības projects. Rìga. 85 lpp. (in Latvian).

Bake, M.A., Vaisla, D., Sudmalis, P. (2003). Chemical Risk for Hairdressers. 8th International Symposium of ISSA Research Section, Athens, 243-244, Proceeding full text CD format 6 pages; http://www.elinyae.gr.
Boman, A., Maibach, H. I. (2000). Influence of evaporation and solvent mixtures on the absorption of toluene and n-butanol in human skin in vitro. Ann. Occup. Hyg., 44, 125-135.

Dick, F. D. (2006). Solvent neurotoxicity. Occup. Environ Med., 63, 221-226.

Eglīte, M. (2000). Ķīmisko faktoru izraisītā arodpatoloğija [Occupational pathology caused by chemical factors]. Grām.: Darba medicinna (136.-352. lpp.). Rìga (in Latvian).

Kal̦kis, V., Roja, Ž. (eds.) (2001). Darba vides riska faktori un strādājošo veselības aizsardzība [Risk Factors of Work Environment and Health Protection of Workers]. Elpa, Rīga. 500 lpp. (in Latvian).

Lacey, J.V., Garabrant, D. H., Laing, T. J., Gillespie, B.W., Mayes, M. D., Cooper, B. C., Schottenfeld, D. (1999). Petroleum distillate solvents as risk factors for undifferentiated connective tissue disease (UCTD). Amer. J. Epidemiol., 149, 761-770.

Lash, L.H., Parker, J.C. (2001). Hepatic and renal toxicities associated with perchloroethylene. Pharmacol. Rev., 53, 177-208.

Linnika, Z., Bake, M.A., Rusakova, N., Matisane, L., Veide, A. (2001). Health risk assessment to perchloroethylene during dry cleaning. Industrial Toxicology, Bratislava, 45-48.

Nilson, L.N., Sällsten, G., Hagberg, S., Bäckman, L., Barregård, L. (2002). Influence of solvent exposure and aging on cognitive functioning: An 18 year follow up of formerly exposed floor layers and their controls. Occup. Environ. Med., 59, 49-57.

Parmeggiani , L. (ed). (1985). Encyclopaedia of Occupational Health and Safety. 3rd edn., vol. 2. Geneva: International Labour Office. 2538 pp.

Pesch, B., Haerting. J, Ranft, U., Klimpel A., Oelschlagel, B., Schill, W. (2000). Occupational risk factors for urothelial carcinoma: Agent-specific results form a case-control study in Germany. Int. J. Epidemiol., 29, 238-247.

Plenge-Bönig, A., Karmaus, W. (1999). Exposure to toluene in the printing industry is associated with sub fecundity in women but not in men. Occup. Environ. Med., 56, 443-448.

Shi, L.-M., Chia, S.-E. (2002). Review of recent epidemiological studies on paternal occupations and birth defects. Occup. Environ. Med., 59, $149-155$.

Teibe, U. (2007). Biologisiskā statistika [Biological Statistics]. Rīga: LU akadēmiskais apgāds. 155 lpp. (in Latvian).

Triebig, G., Hallermann, J. (2001). Survey of solvent related chronic encephalopathy as an occupational disease in European countries. Occup. Environ. Med., 58, 575-581.

Xiao, J. Q., Levin, S. M. (2000). The diagnosis and management of solvent-related disorders. Amer. J. Ind. Med., 44-61.

Баkе М. Я., Лусе И.Ю, Спруджа Д.Р., Кузнецова В.М., Русакова Н.Е. (2002). Факторы риска здоровья медицинских работников [Health risk factors of health care workers]. Ж. Мед. тр. промьшл. экол., 3, 28-33 (in Russian).

Received 9 February 2010

\section{OGANISKIE ŠḲIDDINĀTĀJI KĀ DARBA VIDES K̦IMMISKĀ RISKA FAKTORI DAŽĀDĀS RAŽOŠANAS NOZARĒS UN TO IESPĒJAMĀ IETEKME UZ NODARBINĀTO VESELİBU}

Darbā veikta organisko šḳīdinātāju kā darba vides ḳīmisko riska faktoru novērtēšana Latvijas uznēemumos laika periodā no 1998. līdz 2006. gadam pēc Rīgas Stradina universitātes Darba drošības un vides veselības institūta Higiēnas un arodslimību laboratorijas analī̌̌u datu bāzes. Pētījumā analizētas dažāàdu organisko šḳīdinātāju koncentrācijas darba vides gaisā 116 uzṇēmumos, kuros veikti dažādu grupu organisko vielu (aromātiskie og̣̣ūdeņraži, alifātiski ogḷūdeņraži summāri pēc oglekḷa, spirti, esteri, celosolvi, ketoni, halogenogḷūdeņraži, petrolejas destilācijas produkti) mērījumi 1790 darba vietās. Organisko šḳīdinātāju iedarbības risks darbinieku veselībai vērtēts pēc ekspozīijas indeksa, kas norāda reālās ekspozīcijas attiecību pret normatīvos pię̧auto aroda ekspozīcijas robežkoncentrāciju, un iedarbības varbūtība analizēta pēc iedalījuma trijās pakāpēs: zema (56,7\% mērījumu), vidēja (25,2\% mērījumu) un augsta (18,1\% mērījumu). Škīināāāju sastāvā visbiežāk ietilpst aromātiskie ogḷūdeṇraži (35\% no analī̌̌u kopskaita) toluols un ksiloli, tehniskos produktos novēro arī benzola klātbūtni. Pētījuma dati rāda, ka nodarbinātie bieži ir pakḷauti vienlaicīgi dažādu šk̄īdinātāju iespējamai ietekmei un organiskie šķ̄ininātāji ir nozīmīga darba vides riska problēma Latvijā. 